\title{
The Speech Act of Arabic Communities in Muntok City, Bangka Belitung Archipelago
}

\author{
N Wijayanti ${ }^{1}$, S Ferianda $^{2}$, \& A Fernanda ${ }^{3}$ \\ \{1wijayavita88@gmail.com, ${ }^{2}$ ferianda02021992@gmail.com; ${ }^{3}$ andrifernanda92@yahoo.co.id\} \\ ${ }^{123}$ University of Bangka Belitung
}

Abstract. Muntok is one of the city in Bangka Belitung Archipelago Province that directly attaches with the harbour therefore many other countries came easily to Muntok centuries ago. It means that there is high potential of the society becoming acculturated. This study aims to investigate the acculturation of Arabic descent to Bangka Malay descent especially in Muntok City, West Bangka, Bangka Belitung Archipelago through the language. This research uses theory of speech acts to indicate the probability of the community when facing the phenomenon of acculturation. Babha says that the hybrid notion is a metaphor of two different things that combine to give rise to a characteristic that consequently negates the unique properties inherent in both. In this study the object under study is a two-language fusion that is mixed between Arabic and Bangka Malay descents. The research conducts 8 participants from various background of age and duration of living using descriptive analysis method. The investigation shows that the Arabic intonation they used before was almost destroyed because the community had lived or lived for a long time so that the new intonation used had turned into the intonation of the area they lived in, namely Malay. Therefore, it can be concluded that, even though they still use Arabic words in their daily interaction life, the intonation they use follows the intonation of the area where they lived at that time.

Keywords: Arabic Descent, Speech Acts, Muntok City, Hibridity

\section{Introduction}

The fact is that there are a number of Arab descendants in the City of Muntok, West Bangka, which is evidence of direct contact with Arabs, leaving a trace in this city. After hundreds of years this Arabian breed has been acculturated along with two other races (Chinese and Malay) making the acculturation of culture evident, one of which is seen from the language.

Qurtuby in his journal states that Arab descendants in Indonesia has contribution to the shape of Indonesian Islam, Islamic cultures and Muslim politics. Further, it turns out that some admire and build a strong relationship with the Arab and "Indo-Arab". On the other hands, the rest state that Arab has destroyed Indonesia's local tradition, civic pluralism, social stability, and inter-religious tolerance[1]. This journal states both sides of the contribution of Arab descendant coming to Indonesia by analyzing the changing in local tradition and politics in Indonesia in general. It is too broad to talk Arab descendant coming into Indonesia but which region or society in Indonesia that has specific acculturation since Indonesia itself has many 
cultures. Therefore, in this research, the place being observed is in particular region in Bangka Belitung Archipelago Province called Muntok.

According to Ngugi, a language carries a cultural message and so culture is carried out in oral and written formats (orature and literature) which will be carried on each individual wherever the individual spreads throughout the world [2]. Basically, every individual is equipped to be able to have a mother tongue which will develop as the individual collides with other individuals who may have far different languages, so in the end there will be a language meeting to be able to make their communication into an agreed agreement.

Furthermore, Tayeb Salih in Rogers says that the language of native speakers and cultures will go hand in hand, even when there are foreign language speakers even though they enter a new culture, there is a tendency for one of them to be more dominant [3]. This means that in this case the research on acculturation of Arabic language in Muntok City supports the occurrence of cultural fusion that begins with domination. Said also says that referring to old writings on colonization leads to a better community where cultural hybridity and plural identity dominate [4]. In its application the Arabs did not have the ambition to colonize the Indonesian nation politically but on a 'missionary' or religious mission. So, in this study, we will see further the process of Islamization in Bangka, especially in the City of Muntok, seen in an ethnolinguistic perspective. For this reason, the study of speech acts also makes this research involve pragmatic elements where the speaker and listener do not exclude other contexts that accompany when the speech act takes place. The speaker not only conveys his discussion through emotion through language but also emotions when doing the speech act [5].

Many ethnolinguistic researches elaborate on the relationship between language and culture by providing habitual expression. This supports the author in analyzing the research entitled "The Speech Acts of Arab Peranakan Communities in Muntok City, Bangka Barat Regency, Bangka Belitung Islands" through an ethnolinguistic approach. Through the ethnolinguistic approach, this research is expected to explain the occurrence of the acculturation process of language and culture in the Muntok Society especially on speech acts.

In the study there are two formulation of the problem that will be answered in the discussion session, namely the hybridity process of Arabic peranakan speech acts in the City of Muntok, West Bangka, and factors that influence the hybridity of Arabic peranakan speech acts in the City of Muntok, West Bangka.

\section{Research Method}

In this study, the type of research used is a type of qualitative research in which researchers understand the phenomenon of what is experienced by research subjects such as behavior, motivation, actions, and others. In this study also, qualitative methods are used to obtain an overview of the process of hybridity or the acculturation process that occurs in the fusion of the identity of Arab peranakan communities that occurs because of the influence of Malay and Chinese culture. In addition this method is also used to find out the Speech Acts of Arabian communities that have been mixed with Malay and Chinese cultures. This study uses a descriptive analytical research method approach which means that where a researcher sees the symptoms that occur and then from the description of the phenomenon will be analyzed [6]. Thus, a qualitative approach with descriptive analysis is very relevant to describe the speech act or Speech Acts of Arabian communities in the city of Muntok, West Bangka Regency. 
The research location chosen in this study was the city of Muntok, West Bangka Regency where there are still many Arab people living there. In this study the terms used by the research subjects were informants. The subjects in this study were Arab people who lived in the city of Muntok. There were 10 informants chosen to be the subjects of the study, including 4 (four) adult men, 2 (two) boys, 2 (two) adult women, and 2 (two) girls. The selection of informants was done by purposive sampling technique in which samples were carefully selected according to specific characteristics and characteristics such as, age, length of stay in the city of Muntok [7]. For data retrieval techniques, the technique used in this study is an in-depth interview technique where researchers dig deeper into the information from the informants.

There are several steps taken in carrying out data analysis techniques including data reduction used to select and sort raw data that is still diverse [8]. After reducing data, the data is then displayed systematically in the form of tables, matrices, charts or graphs and so on. After reducing and displaying the data, the next step is the decision making process for the research question. Drawing conclusions here are the results of interviews and small discussions regarding speech acts or the Speech Acts of Arab descent communities. In this study, researchers conducted data analysis by accommodating all incoming data related to research problems in the Muntok City Arab Community.

Furthermore, the research that discusses hybridity with ethnographic studies entitled "Hybrid Identity of Indonesian Christian Chinese: Tension and Negotiation Between Humiliation, Indonesianness and Christianity" by Darwin Darmawan in 2013 where he dismantled negotiations on the identity of Chinese Indonesian Christians in the post-Suharto era. Darmawan also tracks the agency of Christianity in the process of negotiating identity formed. By using ethnographic studies and using the concept of hybridity, researchers then applied it to the Indonesian Christian Church, which was housed in Commerce Street, Jakarta and found that Chinese Indonesian Christian identity in that place was heterogeneous, dynamic and ambivalent in addition to the forms of tension and negotiation between; humiliation, Indonesianness and Christianity which is creating a hybrid identity [9].

Finally, the thesis in 2018 entitled "Hybridity in Protection Hole Novels in Andy Wasis's Grandfather's House: Postcolonial Analysis Anjali Prabhu" by Dyah Prajnyandari discusses how hybridity construction as well as the form of articulation have relationships and relations with the construction that is formed. The novel Lubang Keselamatan at Kakek's House tells the story of a Chinese family with native people. Identity is increasingly complicated when there is interaction with the outside world where there is another identity, namely the Netherlands. In this study explained the meeting process, mixing, and interaction between 3 different identities in the community using Anjali Prabhu's hybridity theory, researchers analyzed the form of hybridity in the novel in terms of both creole and diaspora [10]. Then the researchers uncovered the relationship between the relationship with the construction of hybridity that was formed inside the Protection Hole in Grandpa's House. The researcher then describes it in several forms of relations.

\section{Results And Discussion}

\subsection{Language Hibridity Process of Arabic Society in Muntok City}

Babha says that the hybrid notion is a metaphor of two different things that combine to give rise to a characteristic that consequently negates the unique properties inherent in both. In 
this study the object under study is a two-language fusion that is mixed between Arabic and Bangka Malay [11]

The hybrid process that occurs or that is found in this study lies in the intonation spoken by the speakers or the indigenous people of the Arabian Peranakan in Muntok City. Although the people of Arab descent still often use original Arabic words, however, the intonation they use does not necessarily follow the intonation that is irrelevant. The Arabic intonation they used before was melting and almost destroyed because the community had lived or lived for a long time so that the new intonation used had turned into the intonation of the area they lived in, namely Malay. Therefore, it can be concluded that, even though they still use Arabic words in their daily interaction life, the intonation they use follows the intonation of the area where they lived at that time.

It was mentioned and added by one of the informants named Mr Abang Alfian who said that although many Arab communities lived in the city of Muntok, the culture of Malay culture was still very thick and they were still communicating using dialects and dialects of the local area. He also said that, there were many immigrant communities other than Arab communities who came and lived or settled in the city of Muntok, however, over time, the migrants began to adapt to dialect dialects and the intonation of the Muntok area. Interestingly, he also added that, in fact, the existing Malay accent did not originate from Bangka but was carried by predecessors from the Malaysian sultanate.

"Bahasa Muntok justru bahasa asli Melayu yang belum terpengaruh sama sekali oleh bahasa kampung (Bangka dan sekitarnya)" (Alfian, 47 tahun).

"The language of Muntok is actually a native Malay language that has not been affected at all by the village language (Bangka and its surroundings)" (Alfian, 47 years).

The next informant, which is the parent of Habib Hussain who is called "Abah" also said something similar to the informant, namely even though he was Arabic descent, but his daily life he still used Malay intonation when communicating well with his family or with the surrounding community. Furthermore, this was also the son, Habib Hussain, who said that the brother was given the nickname of the native Malay man, because he was considered to be a kind of people, Arabic people because in his daily life he always uses original Malay words and words from the Malay language (Abah, 70 years). Interestingly, there was one informant, Mr. Assan, who no longer used Arabic in his daily communication life. In addition, he also said that he did not give an obligation to Arabic's son to speak. From the results of interviews, it can be said that Mr. Assan was an Arab descendant who experienced cultural acculturation even though he was native to Arabic but felt he was a native person or community of Bangka.

Two female informants namely Ibu Tariyah and Mrs. Jamila also said that even though they often use Arabic when communicating with fellow Arab descendants, everyday they also still use Malay language with a very strong accent when communicating with the indigenous people of Muntok city. When the researchers interviewed them, they did not find Arabic elements obviously from the two informants. This indicates that the length of their stay in the area is also a factor in the existence of hybridity that occurs in the Muntok Arabic community.

Two child informants, Arsan and Nada, which the research team met and invited to communicate indicated that the speech intonation they used had undergone a change or had undergone hybridity where the intonation they used no longer reflected the Arabic intonation that their parents might have sent down. This indicates that their parents did not require them to communicate using Arabic accent or intonation so that they could easily adapt to their environment. 
Related to what has been conveyed by some informants above, Berry illustrates that hybridity that occurs actually describes or provides an integration, where the informants who have been interviewed still hold their true identity but also want to participate in a wider network [12]. Broadly speaking, it can be said that the original identity they brought remained the Arab Peranakan community, but because they lived and lived in the midst of the wider community of the city of Muntok, they immediately adjusted the situation by merging into the patterns of interaction and communication carried out by the indigenous people of the city Muntok.

\subsection{Speech Acts of the Arabic Community in Muntok City}

Speech act theory is a theory in the field of linguistics that discusses speech as functional unity in communication. Malmkjer classifies the types of speech acts in three categories: act locution (locutionary acts), illocutionary acts, and perlocutionary acts [13]. This study presents an illocutionary act category speech act which discusses the speakers' actions which will then be further developed into 5 (five) types of illocutionary actions namely assertive, directive, commissive, expressive, and declarative.

In illocutionary speech acts which are the efforts of speakers to say something and do something at the same time, the role of speakers from the Arabic Community in Muntok City is to provide information and example of how the acculturation process takes place and is expressed in expression [14]. All informants provide information related to how they view specifically the development of the language they use everyday. These speakers who are Arabic descendants agree that the language they use today is a language that has merged with the Bangka Malay language. Next they said it with different expressions according to their point of view about the fusion of this language which actually became a process of hybridity.

First, assertive illocutionary actions, namely speakers express, declare, make, propose, complain, and express opinions where speakers are bound to the truth of the position expressed. Secondly, directive illocutionary actions aim to produce an effect in the form of actions taken by the speaker, for example, ordering, ordering, demanding and giving advice. Third, commissive illocutionary actions are speakers bound to future events that are promising and offering. The fourth type is expressive illocutionary action which is to know the psychological attitude of the speaker when delivering his speech, for example when saying thank you, forgiving, praising, and criticizing. The last type is the illocutionary act of declaration where there is a match between the content of propositions and reality, for example resigning, baptizing, firing, naming, punishing, locking and lifting.

The result shows that there are 4 amounts of expressive, 10 amounts of assertive, and 1 amount of directive. Meanwhile, there is no result of commisive and declarative illocutionary acts.

\subsection{The Process of Hybridity of Actions of the Arab Peranakan Community in Muntok City}

The fusion of identity including the use of language is an absolute thing to be seen in the community in the City of Muntok, West Bangka, specifically the melting of Arab identity into the Muntok distinctive Malay identity. This is supported by the statement Sibarani which states that ethnolinguistics is a variation in the use of language related to the development of time, differences in place of communication, kinship system, influence of ethnic habits, beliefs, language ethics, customs, and other cultural patterns of a language tribe [15]

Departing from the support of language and culture, language hybridity became very pronounced in the blend of one identity namely Arabic identity and Chinese and Malay identity. 
This can be seen in conversations carried out by residents of Muntok Arab descent who use the language of Muntok eloquently, and these residents consciously declared that he was born and lived in Muntok since the generation of his grandfather. That is, even though he himself uses Bangka Malay language to his family he uses Arabic only during religious activities [16]. Arabic terms are still used but are only limited to the name of recitation activities and also pilgrimages which are not only followed by Arabic descent but also Chinese and Malay descents.

On the same occasion, a speaker named Habib Husen who was an Arab breeder admitted that he still used Arabic vocabulary in daily conversations, as in the example below:

Eh, gahwa (kopi) dak de kah?

(Eh, there is no gahwa? (coffe))

Ana tak bise pergi ke surau, takban (capek)

(Ana (I) cannot go to the mosque, takban (tired))

Kau makan tak pakai suduk (sendok) ke?

(You don't eat using a suduk (spoon), eh?)

It is said that their families are still in contact with families in Yemen so they still have to speak Arabic to be able to bridge communication between extended families.

The next informant, namely the parents of Habib Hussain who was called "Abah" also said something similar to what was said by the previous informant, namely even though he was of Arab descent, but in his daily life he still used Malay intonation when communicating well with his family or with the surrounding community. Furthermore, this was also added by his son, Habib Hussain, who said that the brother was given the nickname of the native Malay man Muntok because he was considered to know all kinds of words that sounded foreign and were unknown to the native Muntok people, and were considered no longer Arabic people because in his daily life he always uses original Malay intonation and words from the Malay language. Interestingly, there was one informant, Mr. Assan, who no longer used Arabic in his daily communication life. In addition, he also said that he did not give an obligation to his son to speak Arabic. From the results of interviews conducted with him, it can be said that Mr. Assan was an Arab descendant who experienced cultural acculturation even though he was native to Arab descent but he felt he was a native person or community of Bangka.

In terms of speech acts, some speakers convey their speech acts in illocutionary view, namely assertively, expressively, and directively. Assertively the speaker expresses, states, makes, proposes, complains, and expresses opinions where the speaker is bound to the truth of the position expressed.

'Disini tidak ada istilah Arab yang digunakan, saya sendiri bukan dari Arab tetapi Yaman' (Assan, 62 tahun).

'Here there is no Arabic term used, I myself am not from Arabic but Yemen' (Assan, 62 years).

'Bahasa Muntok justru bahasa asli Melayu yang belum terpengaruh sama sekali oleh bahasa kampung (Bangka dan sekitarnya)' (Alfian, 47 tahun).

'The Muntok language is actually a native Malay language that has not been affected at all by the village language (Bangka and its surroundings)' (Alfian, 47 years).

In the dialogue above, it can be concluded that speakers provide information regarding the clarification of the arrival of Arabian breeders not from Arabia but Yemen. Furthermore, there is information that Muntok Malay is a native Malay language but has been influenced by the 
language of the village. The language of the village in question is influence from outside West Bangka.

Expressively, this speech act knows the psychological attitude of the speaker when delivering his utterances, for example, when expressing gratitude, forgiveness, praise, and criticism. In this case some of the speakers clearly stated personal opinions accompanied by a sense of complaint and also pride as in the quotation below:

'Masalah bahasa ini saya sendiri prihatin karena banyak orang di Muntok ini sudah lain bahasanya, karena mereka meniru bahasa-bahasa di televisi'(Abah, 70 tahun).

I am concerned about this language problem because many people in Muntok have another language, because they mimic the languages on television '(Abah, 70 years).

'Saya tetap memegang syariat Islam dan menyekolahkan anak-anak saya ke pesantren dan meminta mereka belajar bahasa Arab dan tafsir kitab'(Assan, 62).

'I still hold Islamic law and send my children to Islamic boarding schools and ask them to learn Arabic and interpretations of the book'(Assan, 62).

It appears that there is an expression of concern or regret that the Muntok Malay language has been mixed with other regional languages. This is because the speakers came from the Malaysian kingdom of Arab descent who did not even use Arabic. While other speakers said that they were proud to be part of the West Bangka community and were more proud to be able to maintain Islamic law.

The last type is the illocutionary directive which aims to produce an effect in the form of an action taken by the speaker, for example, ordering, ordering, demanding and giving advice. In this study there is only one speaker who conducts directive illocutionary speech acts who try to provide views and advice for future generations to do.

'Sebaiknya orang-orang di Muntok tetap melestarikan bahasa kita sendiri. Saya sendiri tetap adalah orang Muntok lahir besar tua di Muntok.' (Assan, 62 tahun).

'We recommend that people in Muntok continue to preserve our own language. I myself still am a Muntok born old man in Muntok. '(Assan, 62 years old).

Based on the previous studies, this research conducts more specific background about the place and it is seen through linguistic study, which is speech act. The acculturation that has been discussed by the previous study is the the general acculturation adding by political views. The result also serves two sides, which are pro and contrast about Arab descendant in Indonesia.

This research serves the hybridization result happened in Muntok city based on linguistic perspective. Basically Arabic and Bangka Malay have different twists or intonations. In this study, it can be heard that the crookedness of language hybridity can begin to be seen from the shift of cengkok arab to cengkok Melayu. However, there is something more interesting than the two hooks, namely the creation of a new crooked Bangka Malay grip. So that in the case of this intonation language hybridity proves that there is a new identity carried by two old identities.

\section{Conclusion}

Related to the hybridity of speech acts that occur in Arabian descendants in the city of Muntok, researchers found that there were many people who regretted the Muntok Malay Language mixed with the language "kampong" which is a language outside West Bangka. In addition, it can be concluded also that Culture and Language by the peranakan community have merged into a habit that is also carried out by the community outside the Arab peranakan. The 
mixing of languages between Malay and Arabic has been recognized and agreed upon by Arab descendants but there are still people who regret this because of the inevitable touch of modernity such as languages that emerge from television and the internet or other languages such as English .

Regarding the hybrid process that occurred or found in this study, the hybrid process lies in the intonation spoken by the speakers or indigenous Arabic descent in the City of Muntok. Although the people of Arab descent still often use original Arabic words, however, the intonation they use does not necessarily follow the intonation that is irrelevant. The Arabic intonation they used before was almost destroyed because the community had lived or lived for a long time so that the new intonation used had turned into the intonation of the area they lived in, namely Malay. Therefore, it can be concluded that, even though they still use Arabic words in their daily interaction life, the intonation they use follows the intonation of the area where they lived at that time.

\section{Acknowledgement}

The authors would like to say thank you for One Asia Foundation that supports us with the grants, Dean of Faculty of Social and Political Science, and other people whose contribution encourage us to finish this research.

\section{About The Author(S)}

The authors are team research from English Department Faculty of Social and Political Science of University of Bangka Belitung. The field of the authors is linguistics and literature.

\section{References}

[1] S. Al Qurtuby, "Arabs and 'Indo-Arabs' in Indonesia:Historical dynamics, social relations and contemporary,” Int. J. Asia Pacific Stud. 13, vol. 2, pp. 45-72, 2017.

[2] W. T. Ngugi, "Decolonizing the Mind: The Politics of Language in African Literature Nairobi.," East African Educ. Publ., 1986.

[3] Tayeb Salih, Season of Migration to The North (New York Review Book Classics). New York: NYBooks, 2012.

[4] B. Ashcroft, Edward Said. New York: Routledge, 2001.

[5] S. Akbar, "Analisis Tindak Tutur pada wawancara putra nababan dan presiden portugal ( kajian pragmatik)," Sesaba J. Pendidik. Bhs. dan Sastra Indones., vol. 1, no. 1, 2018.

[6] M. Idrus, Metode Ilmu Pengetahuan Sosial Pendekatan Kualitatif dan Kuantitatif. Yogyakarta: Gelora Aksara Pratama, 2009.

[7] B. Bungin, Dimensi Metodologi dalam Penelitian. Surabaya: Usaha Nasional, 2004.

[8] B. dan I. Rahman, Menyusun Proposal Penelitian. Bangka: UBB Press, 2009.

[9] D. Darmawan, "Identitas Hibrid Orang Cina Indonesia Kristen: Ketegangan Dan Negosiasi Antara Kecinaan, Keindonesiaan dan Kekristenan,” Universitas Gadjah Mada, Yogyakata, 2013.

[10] D. Prajnyandari, "Hibriditas dalam Novel Lubang Perlindungan di Rumah Kakek karya Andy Wasis: Analisis Pascakolonial Anjali Prabhu.," Universitas Gadjah Mada, 2018.

[11] H. K. Bhabha, Our Neighbours, Ourselves: Contemporary Reflections on Survival. New York: Walter de Gruyter GmbH \& Co, 2011. 
[12] J. . Berry, “. Immigration, Acculturation, And Adaptation,” Appl. Psychol. An Int. Rev., vol. 46, no. 1, pp. 5-68, 1997.

[13] K. Malmkjer, The Linguistics Encyclopedia. London: Routledge, 2006.

[14] I. D. P. dan M. R. Wijana, Analisis Wacana Pragmatik: Kajian Teori dan Analisis. Surakarta: Yuma Pustaka, 2010.

[15] R. Sibarani, Antropolinguistik: Antropologi Linguistik, Linguistik Antropologi. Medan: Penerbit Poda, 2004.

[16] K. Saddhono, N. E. Wardani, and C. Ulya. "Sociopragmatic approach on discourse structure of friday prayer's sermon in java and madura island." J. of Lang and Lit, vol. 6 no. 1 pp 26-29, 2015 